\title{
THE INFLUENCE OF KNOWLEDGE SOURCES ON FIRM- LEVEL INNOVATION: THE CASE OF SLOVAK AND HUNGARIAN MANUFACTURING FIRMS
}

\author{
Odei, S. A., Stejskal, J.
}

This paper seeks to examine the various sources of knowledge and innovation that Slovak and Hungarian manufacturing firms rely on to improve their innovative performance. To carry out our empirical analysis we used the multiple regression technique and data from the Community Innovation Survey conducted between 2010 and 2012. Our empirical analysis demonstrated divergent results for both countries. Slovak firms derived their innovation from in-house activities and other sources such as scientific journals and conferences while Hungarian firms relied on market sources such as cooperation with clients or customers from the private sector for their innovation as well as from scientific journals. However, there was a convergence in the results, manufacturing firms in both countries didn't collaborate with research institutions such as universities and other public and private research organization for their innovation. This study, therefore, proposes firms to foster closer collaboration with these research institutions since they are the birthplaces of innovation that can increase their competitiveness and innovation performance.

Keywords: Innovation; knowledge; knowledge sources; innovation performance; Slovakia; Hungary

JEL Classification: L60, 030, 033

\section{Introduction}

The increasing attention given to knowledge spillovers has drifted scholarly attention to sources of knowledge and innovation. The innovative prospects of firms need knowledge from diverse and reliable sources to succeed. Firm's innovation progressively depends on their ability to assimilate and appropriate external knowledge, technologies and information. Firms derive their innovation from diverse sources such as R\&D cooperation with customers and suppliers, competitors, universities, fairs and trade associations and public research organizations and these sources increase their innovative performance (Tether, 2002). Firms are increasingly depending on research institutions and other higher

An earlier version of this paper has been published at the 6th International Conference Innovation Management, Entrepreneurship and Sustainability (IMES 2018) 
educational institutions such as universities as a source of their knowledge and innovation (Belderbos et al., 2016; Laursen \& Salter, 2004). Knowledge from these external sources helps firms to bolster their competitiveness as well as their innovation performance.

Firms that have an open search strategy tend to draw their innovation from research institutions such as university and other private and public research organizations (Dahlander \& Gann, 2010). Research outcomes from universities can directly be converted into new products or services for industrial development (West \& Bogers, 2014). Universities have embraced their "third mission" which comprises of a broad range of activities such as disseminating their research results to wider coverage outside their academic campuses and this has resulted in increased direct collaboration with industries. Industries have realized that short-term research outputs from public research organizations and universities can position them better in the highlycompetitive market. Firms can rely on basic research to help in the development of new goods and services.

The remainder of our paper is organized into five sections. Section 2 focuses on theoretical background on the sources of firm's knowledge and innovation. Section 3 is devoted to the methodology describing the sources and method used for our empirical analysis. Section 4 focuses on descriptive results, while section 5 contains discussions and conclusion with some policy implications.

\section{Theoretical Background}

New knowledge firms acquire from diverse sources creates innovation within firms. Firms rely on various sources for this new knowledge and innovation. Their competitiveness and innovative performance dangle on how successful they are at utilizing knowledge emanating from these numerous sources (Leiponen \& Helfat, 2010; West \& Bogers, 2014). Schumpeter describes firms' innovation search as a process where firms explore other avenues to look for new combinations of knowledge and other vital technologies for their products and processes. Firms' innovation performance soars when they search for knowledge and innovation internally within the firms' confines and externally from outside the boundaries of the firms. Internally firms can gain knowledge through in-house research and development $(\mathrm{R} \& \mathrm{D})$ activities as well as from the regular internal staff education and training programs (Berchicci, 2013; Grigoriou \& Rothaermel, 2017). External knowledge available to firms can only be acquired when firm enter into synergies with higher educational institutions such as universities and other research institutions, clients, customers and suppliers and with other firms (Grigoriou \& Rothaermel, 2017; Vrontis et al., 2017).

Firms can acquire knowledge and innovations internally through in-house research and development activities and processes (Cassiman \& Veugelers, 2006). In-house activities have become a vital source of new knowledge for firms. This involves deliberate activities carried out by employers to sharpen employee skills (Beneito, 2006). These in-house 
activities comprise of organized internal education, workshops, coaching, mentoring and other training programs to further build and increase the internal knowledge-base of employees. Training activities updates staff knowledge with current technologies, hence sprouting human capital, absorptive capacity and individual innovation performance (Santamaría et al., 2009).

Firms invest substantial amounts of resources such as money and time in search of improved knowledge and innovation (Berchicci, 2013). Firms can derive their innovations externally from the market environment. Innovation emanating from market sources play a key role in firm's innovation and can lead to business success or failure. Competition among firms can force firms to innovate to survive. Market rivals (competitors) contribute to firm's innovation by providing complementary assets for R\&D and technology (Miotti $\&$ Sachwald, 2003). The intense market competition for customers means that firms will always find innovative ways to differentiate themselves from other rivals (Hashmi, 2013). Firms can rely on product design to create corporate uniqueness and improve products to give them new and attractive looks. Additionally, firms' access to local and foreign markets can enable them to access to foreign technologies as well as to facilitate their market expansion. Clients and customers can influence new product development by providing complementary knowledge of their taste, requirements and preferences (Carayannis et al., 2015). These vital collaborations and exchanges in the supply chain between producers and consumers help in product improvements leading to a towering likelihood that these new products will be adopted by consumers.

Furthermore, suppliers of equipment and materials can offer essential insight into the planning of logistics, production and other functions. Suppliers are also reliable sources of information because they act as the bridges between producers and consumers ensuring the flow of vital knowledge and ideas needed to develop or improve products or processes (Yeniyurt et al, 2014). Suppliers of equipment and materials offer firms insight into the organization of the production process, they provide firms with the needed knowledge and after sale services (Zhang \& Gallagher, 2016). Suppliers of equipment and materials possess the technological know-how, and they can transfer this to firms when they are in constant interactions (Cui et al., 2015). When there is a new technology, due to their connection with firms, they can inform them to stay abreast.

Firms have come to realize they cannot innovate in isolation without depending on $R \& D$ activities from other research institutions (Prokop \& Stejskal, 2018). Therefore, firms are increasingly looking for other sources to supplement their in-house knowledge production capabilities that allow access to codified and tacit academic knowledge from other extraneous sources, and this is through collaborating with innovation centers such as research institutions (Laursen \& Salter, 2014). Universities (public research institutions) are knowledge avenues and firms can partner with them and absorb knowledge associated with research activities (Arocena et al., 2015; Odei \& Stejskal, 2018). University knowledge increases industrial innovation and can champion the establishment of new 
industries. Academic research is driven by both economic and social motives, so firms will demand these innovations so long as they remain in competition and production (Odei, 2017). This collaboration comprises the cooperation with institutions such as universities, private and public research organizations. This collaboration can be through joint research and other academic consulting or training activities. This relates to the knowledge and technology transfers networks and the spillover effect of research outcomes that can be appropriated by firms for further commercialization. Universities can disseminate knowledge and information and can transform codified academic knowledge into commercial values (Siegel et al., 2004). Firms can appropriate knowledge from universities in their production process and this can lead to improved outputs and services for consumers.

The next source of knowledge and firm-level innovation is the knowledge gained from public gatherings and other knowledge sharing events (Lin, 2007). This basically involves all the informal occasional social meetings such as joint conferences, meetings, workshops jointly organized by industry and academia. These mediums allow businesses to interact among themselves and with knowledge institutions as well as with experts and this can lead to the transmission of both tacit and codified knowledge (Jensen et al., 2007). Experts with knowledge and expertise are usually invited to these meetings to share ideas and knowledge that may be beneficial to the business community. Professional conferences and industrial associations can also be essential media that connect and strengthen businesses collaborations with academia (Perkmann \& Walsh, 2008). A study by Cohen et al., (2002) on R\&D executives in the USA found among other things that academic consulting and other academic activities such as conferences were understood to be the most essential avenues for advancing knowledge and allowing firms to gain access to university research.

In recent times, scientific journals and publications have increasingly become an important source of knowledge and innovations for firms (Sorenson \& Fleming, 2004). Researchers use scientific or scholarly journals to communicate the outcomes of their research to the large audience such as business and the academic community (Straub \& Ang, 2011). This makes scientific journals important mediums of knowledge transfers. Scientific journals usually target business practitioners and top-level management and executives although they are mostly written by researchers and academics. They are believed to be efficient and effective channels to transmit knowledge and firm-level innovation from academia to businesses (Jabagi et al., 2016; Straub \& Ang, 2011). According to Lee (2000, p. 355), scientific journals are "the publication of research that would appeal immediately to managers, executives, consultants, and other practitioners". Similarly, in the view of Straub and Ang (2008) "academic-practitioner journals are written by either academics or practitioners but are pitched mostly at a professional audience". The results and policy recommendations of these scientific papers become useful to businesses and they can be adopted and implemented as solutions to business problems. 
Lastly, consultants, commercial laboratories and other private R\&D institutes have also become important sources of knowledge for firms. Consulting is increasingly becoming one of the important formal means of interaction between consultants (mostly faculty members) and the non-academic institutions such as industries (Perkmann et al., 2013). This can be in the form of consultants providing advisory services or research instigated and funded by firms (Perkmann \& Walsh, 2007, 2008) to industries. Consultants in commercial laboratories and other private $R \& D$ institutes frequently engage in knowledge transfer activities, interact with industries through their research and this helps to impact industrial R\&D (Cohen et al., 2002). Consultants ensure closer contacts between industrial partners leading to mutually beneficial outcomes for both consultants and industries. This mode of knowledge transfer provides academic researchers (consultants) the opportunity to identify new research areas and topics (Buenstorf, 2009).

The aim of this paper is to examine the various sources of knowledge and innovation for manufacturing industries in Slovakia and Hungary. Firm's knowledge of sources of knowledge and innovation makes them survive the intense competition, increase their productivity, efficiency and profitability (Stejskal \& Hajek, 2012). This study found limited studies on the sources of knowledge and innovation for manufacturing firms in Slovakia and Hungary (see Damijan et al., 2003; Grillitsch \& Trippl, 2014). In both countries, the manufacturing sectors are the leading drivers of economic growth and innovation (Dudin et al., 2016). This paper intends to add to the literature on innovative collaboration in these countries.

\section{Methodology and Data}

Data for the empirical analysis originates from the Eurostat Community Innovation Survey (CIS) of innovation conducted between 2010 and 2012. The methodology and all the questions of the CIS innovation surveys are thoroughly explained in the Organization for Economic Co-operation and Development's (OECD) Oslo Manual. The use of CIS data in firm-level innovation studies in Europe and other continent has soared (Leiponen \& Helfat, 2010). CIS surveys are frequently conducted every two years by all EU member states as well as Iceland and Norway. The subject-oriented CIS questionnaire asks firms to point out their source of technological knowledge and information that influences their innovative activities. The CIS identifies 11 different sources of information and knowledge for firms' innovation and they include within the industry, universities, suppliers, and customers among others. The advantage of using CIS data is that it serves as a useful alternative to the customary measures of innovation, using the number of patents acquired as a proxy (Laursen \& Salter, 2004).

This paper subsequently used the regression model for our analysis by sampling 3,576 manufacturing firms with at least fifty employees (869 from Slovakia and 2,707 from Hungary). The regression model is usually used for this kind of analysis because it establishes the relationship between the dependent variable and independents variables 
(Preacher et al., 2006). Therefore, it enabled us to verify how sources of knowledge and innovation influence firm's innovation performance. Numerous studies have used the regression technique in this regard (Ingram et al., 2016; Schneider \& Spieth, 2013). The general formula of the linear regression model is given by Chatterjee and Hadi (2015) as follows:

$$
y=\beta_{0}+\beta_{1} \mathrm{x}_{1}+\beta_{2} \mathrm{x}_{2}+\ldots+\beta_{n} x_{n}+\varepsilon
$$

where:

- $\quad y$ is the dependent variable;

- $\quad x_{1}, x_{2} \ldots x_{n}$ are the independent variables;

- $\varepsilon$ is an error term that accounts for the variability in $y$ that cannot be explained by the linear effect of the $n$ independent variables.

The lists of independent variables are explained in table 1.

Table 1 | Independent variables

\begin{tabular}{|c|c|c|c|}
\hline Internal sources & Market sources & Institutional sources & Other sources \\
\hline \multirow[t]{4}{*}{$\begin{array}{l}\text { within the enterprise or } \\
\text { enterprise grouph } \\
\text { (SENTG) }\end{array}$} & $\begin{array}{l}\text { Clients or customers } \\
\text { from the public sector } \\
\text { (SCLPU) }\end{array}$ & $\begin{array}{l}\text { Universities or other } \\
\text { higher education } \\
\text { institutes (SUNI) }\end{array}$ & $\begin{array}{c}\text { professional } \\
\text { conferences, trade fairs, } \\
\text { meetings (SCON) }\end{array}$ \\
\hline & $\begin{array}{l}\text { Competitors and other } \\
\text { enterprises of same } \\
\text { industry } \\
\text { (SCOM) }\end{array}$ & $\begin{array}{l}\text { Government or public } \\
\text { research institutes } \\
\text { (SGMT) }\end{array}$ & $\begin{array}{l}\text { Scientific journals, } \\
\text { trade/scientific } \\
\text { publications (SJOU) }\end{array}$ \\
\hline & $\begin{array}{l}\text { Suppliers of equipment, } \\
\text { materials, etc. } \\
\text { (SSUP) }\end{array}$ & $\begin{array}{l}\text { consultants, commercial } \\
\text { labs or private R\&D } \\
\text { institutes } \\
\text { (SINS) }\end{array}$ & $\begin{array}{c}\text { Professional and } \\
\text { industry associations } \\
\text { (SPRO) }\end{array}$ \\
\hline & $\begin{array}{l}\text { Clients or customers } \\
\text { from the private sector } \\
\text { (SCLPR) }\end{array}$ & & \\
\hline
\end{tabular}

Source: Own elaboration 


\section{Results and Discussion}

We start by looking at the sources from which Slovak and Hungarian firms derive their innovation. First of all we focus on firms that highly depend on universities as their sources of knowledge and information. In the CIS firms are asked to indicate the degree of importance of all the sources of knowledge or information for their innovative activities on a scale of 0-1-2-3, (0: meaning not used; 1: low use; 2: Medium use and 3: meaning high use).

Table 2 | Slovak and Hungarian firms relying on universities for their innovation

\begin{tabular}{|c|c|c|c|c|c|c|c|c|c|c|c|c|}
\hline \multicolumn{7}{|c|}{ Slovakia } & \multicolumn{6}{|c|}{ Hungary } \\
\hline Industries & $\begin{array}{l}\text { Not } \\
\text { used } \\
(\%)\end{array}$ & $\begin{array}{l}\text { Low } \\
\text { use } \\
(\%)\end{array}$ & $\begin{array}{l}\text { Mediu } \\
\text { m use } \\
(\%)\end{array}$ & $\begin{array}{l}\text { High } \\
\text { use } \\
(\%)\end{array}$ & $\begin{array}{l}\text { Row } \\
(\%)\end{array}$ & Total & $\begin{array}{l}\text { Not } \\
\text { used } \\
(\%)\end{array}$ & $\begin{array}{l}\text { Low } \\
\text { use } \\
(\%)\end{array}$ & $\begin{array}{l}\text { Mediu } \\
\text { m use } \\
(\%)\end{array}$ & $\begin{array}{l}\text { High } \\
\text { use } \\
(\%)\end{array}$ & $\begin{array}{l}\text { Row } \\
(\%)\end{array}$ & Total \\
\hline $\begin{array}{l}\text { Food, } \\
\text { beverages } \\
\& \text { tobacco }\end{array}$ & 20.4 & 4.3 & 3.2 & 1.1 & 71 & 93 & 12.3 & 4.5 & 5.5 & 3 & 74.7 & 440 \\
\hline Textiles & 12.8 & 3.5 & 0 & 1.2 & 82.5 & 86 & 5.7 & 1.5 & 0 & 0.4 & 92.4 & 263 \\
\hline Wood & 17.1 & 5.7 & 0 & 1.4 & 75.8 & 70 & 6.8 & 2 & 4.1 & 2 & 85.1 & 296 \\
\hline $\begin{array}{l}\text { Chemical } \\
\text { products }\end{array}$ & 26.1 & 13 & 17.4 & 4.3 & 39.2 & 23 & 24.5 & 9.2 & 20.4 & 11.2 & 34.7 & 98 \\
\hline $\begin{array}{l}\text { Pharmaceu } \\
\text { ticals }\end{array}$ & 16.7 & 0 & 16.7 & 8.3 & 58.3 & 12 & 11.4 & 8.6 & 22.9 & 14.3 & 42.8 & 35 \\
\hline $\begin{array}{l}\text { Plastics } \\
\text { products }\end{array}$ & 14.1 & 8.5 & 4.2 & 2.1 & 71.1 & 142 & 12.3 & 5 & 6.3 & 5.3 & 71.1 & 301 \\
\hline $\begin{array}{l}\text { Metals } \\
\text { products }\end{array}$ & 13.5 & 3.6 & 3.6 & 1.8 & 77.5 & 111 & 8.7 & 3.1 & 3.8 & 1.8 & 82.6 & 392 \\
\hline Electronic & 29.4 & 8.8 & 0 & 0 & 61.8 & 34 & 13.8 & 5.1 & 8 & 6.5 & 66.6 & 138 \\
\hline Electrical & 14 & 22.8 & 3.5 & 1.8 & 57.9 & 57 & 20.4 & 7.4 & 6.8 & 3.1 & 62.3 & 162 \\
\hline Machinery & 15.4 & 9 & 7.7 & 2.6 & 65.3 & 78 & 20.8 & 5.9 & 7.4 & 4 & 61.9 & 202 \\
\hline Transport & 21.4 & 10 & 5.7 & 0 & 62.9 & 70 & 22.1 & 4.5 & 6.5 & 5 & 61.9 & 199 \\
\hline Others & 10.8 & 4.3 & 1.1 & 0 & 83.8 & 93 & 14.7 & 4.8 & 4 & 2.2 & 74.3 & 272 \\
\hline Total & 211.7 & 93.5 & 63.1 & 24.6 & 807.1 & & 173.5 & 61.6 & 95.7 & 58.8 & 810.4 & \\
\hline $\begin{array}{l}\text { Cumulative } \\
(\%)\end{array}$ & 17.64 & 7.79 & 5.26 & 2.05 & 67.26 & 100 & 14.46 & 5.13 & 7.98 & 4.9 & 67.53 & 100 \\
\hline
\end{tabular}

Source: Own elaboration

As shown in Table 2, Slovak pharmaceutical companies highly depend on universities for their sources of knowledge and innovation, followed by chemical products firms. Additionally, machinery industries and firms producing plastic products also highly rely on firms for their innovation. Firms in the transportation and electronic industries didn't rely on universities as a source of their innovation. On the other hand, the results for Hungarian 
firms that highly used universities as a source of their innovation are similar to that of Slovakia. Pharmaceutical companies were the industry that highly depended on universities for their knowledge this was closely followed by firms producing chemical products. Electronic and plastic products firms as well as firms in the transport industry also highly relied on universities for their innovation.

Again, we examined the other sources of knowledge and innovation for firms that influences their innovative performance in both countries and the results are shown in table 3 below.

Table 3 | Sources of innovation for Hungarian and Slovak firms

\begin{tabular}{|c|c|c|}
\hline & $\begin{array}{c}\text { Slovakia } \\
R^{2}=0.1057 \\
R_{\text {adj }}^{2}=0.0642 \\
P=0.0046\end{array}$ & $\begin{array}{c}\text { Hungary } \\
\mathrm{R}^{2}=0.0426 \\
\mathrm{R}^{2}{ }_{\text {adj }}=0.0280 \\
\mathrm{P}=0.0115\end{array}$ \\
\hline \multicolumn{3}{|c|}{ Internal sources } \\
\hline SENTG & $0.0277^{* *}$ & 0.7332 \\
\hline \multicolumn{3}{|c|}{ Market sources } \\
\hline SSUP & 0.1016 & 0.3434 \\
\hline SCLPR & $0.0837^{\star}$ & $0.0324^{\star *}$ \\
\hline SCLPU & 0.1455 & 0.2037 \\
\hline SCOM & 0.6965 & $0.0582^{*}$ \\
\hline \multicolumn{3}{|c|}{ Institutional sources } \\
\hline SINS & 0.2056 & 0.6967 \\
\hline SUNI & 0.5919 & 0.5951 \\
\hline SGMT & 0.6416 & 0.3757 \\
\hline \multicolumn{3}{|c|}{ Other sources } \\
\hline SCON & $0.0002^{* \star *}$ & 0.8735 \\
\hline SJOU & $0.0116^{* *}$ & $0.0151^{\text {** }}$ \\
\hline SPRO & 0.7147 & 0.6379 \\
\hline
\end{tabular}

Note: ${ }^{*}$ - significant at the 0.05 level; ${ }^{* *}$ - significant at the 0.01 level, ${ }^{* * *}$ - significant at the 0.001 level

Source: Own elaboration

It can be seen from Table 3 that Slovak firms derived their innovations and knowledge from internal sources within the enterprise or enterprise group $\left(0.0277^{*}\right)$. Market sources didn't contribute to firms' innovation as can be seen from the lack of significance of the indicators. The only exception was clients or customers from the private sector (0.08), this confirms the results of (Laursen \& Salter, 2004). Again, the results show that Slovak firms do not cooperate with institutions such as universities, government or other public research organizations, and private research institutions and consultants. This might be due to issues 
such as divergent institutional aims, lack of consensus on property rights, patents, and confidentiality issues might occur (McAdam et al., 2008). These institutions are the major sources of innovation, so the lack of significance confirms other studies that firmsinstitutional collaboration is limited (Bušíková, 2011). Again, other sources of innovation such as professional conferences, trade fairs, meetings, and scientific journals, trade or scientific publications were highly significant sources of innovation for Slovak firms. They demonstrated to be significant at $0.0116^{* *}$ and $0.0002 * * *$ respectively.

On the other hand, the results for Hungary are quite different from that of Slovakia shown above. Among all the innovation sources this study examined, internal sources from within the enterprise or enterprise groups were not a significant source of innovation for manufacturing firms in Hungary. Among all the market sources of innovation, only sources from clients or customers from the private sector have been found to be a significant source of innovation; all the other sources, such as clients or customers from the public sector, suppliers of equipment, materials, etc. and competitors, such as enterprises of same industry, have not found to be significant sources of innovation for manufacturing firms.

Again, institutions (higher education and other private research institutions) which are often seen as homes of innovation have not been so beneficial for these firms. Innovation and knowledge from these research institutions (universities inclusive) didn't contribute as significant sources of innovation, this contradicts (Frenz \& Ietto-Gillies, 2009) conclusion that collaborative knowledge sources are significant sources of firm's innovation. This result also implies that there is no synergy among research institutions (universities, research organizations) and industries. Among the other sources of innovation, it was only the scientific journals and trade/scientific publications sources that were significant sources of these firms' innovation $\left(0.0151^{*}\right)$. The rest, such as professional conferences, trade fairs, meetings and professional and industry associations, were not significant drives of firm's innovation.

\section{Conclusion}

The production, exploitation and absorption of new forms of knowledge by firms to create new products have become a crucial necessity for innovation. Firms mostly have two main sources of knowledge for innovation that influence their innovative performances, and this can be lumped into internal and external sources. Firms derive knowledge internally within the confines of the firm or the enterprise group through in-house knowledge diffusion, research and development, and internal education and training activities for employees. External knowledge acquisition involves the introduction of new knowledge from extramural sources through the procurement of machinery and equipment, employing qualified personnel, professional conferences, trade fairs, meetings, professional and industry associations, training, workshops and licensing. 
Our paper produced divergent results for both countries. Slovak manufacturing firms derive their innovations mainly from internal sources in the enterprise or enterprise consortium, as well as from other sources such as from scientific journals, trade and scientific publications and professional conferences and trade fairs. The results of innovation from institutional sources were not significant in demonstrating that firms do not collaborate with universities, public and private research organizations. On the other hand, Hungarian firms derived their source of innovation from market sources such as from clients or customers from the private sector and scientific journals, trade and scientific publications. Innovation from scientific journals, trade and scientific publications were significant for both countries.

The results of the empirical analysis, therefore, call for policy recommendations. This study recommends firms to strengthen their collaboration with higher educational institutions such as universities and other public and private institutions since they are the birthplaces of scientific innovation when this is done, they can have access to sustainable innovation needed increase their competitiveness.

Admittedly, this research is constrained by certain possible limitations that could prevent its use for absolute generalization due to its only focus on just the manufacturing industries in Slovakia and Hungary. We therefore recommend further studies that will fully incorporate all sectors and all sources of knowledge and innovation in both countries; this will help point out the variations in knowledge sources and their influence on firm-level innovation performances. Additionally, our research does not provide a true picture of the status quo in the manufacturing sector in both countries because our data sources are not current.

\section{Acknowledgment}

This work was supported by grant provided by the scientific research project of the Czech Sciences Foundation Grant No: 17-11795S.

\section{References}

Arocena, R., Göransson, B., \& Sutz, J. (2015). Knowledge policies and universities in developing countries: Inclusive development and the "developmental university". Technology in Society, 41, 10-20.

Belderbos, R., Gilsing, V. A., \& Suzuki, S. (2016). Direct and mediated ties to universities: "Scientific" absorptive capacity and innovation performance of pharmaceutical firms. Strategic Organization, 14(1), 32-52.

Beneito, P. (2006). The innovative performance of in-house and contracted R\&D in terms of patents and utility models. Research Policy, 35(4), 502-517. 
Berchicci, L. (2013). Towards an open R\&D system: Internal R\&D investment, external knowledge acquisition and innovative performance. Research Policy, 42(1), 117 127.

Buenstorf, G. (2009). Is commercialization good or bad for science? Individual-level evidence from the Max Planck Society. Research Policy, 38(2), 281-292.

Bušíková, A. (2011). University-industry collaboration in Slovakia in comparison with other EU countries and the US: what can we learn. In Proceedings from int. conference Management Challenges in the 21st Century. Trenčín: Vysoká škola managementu v Trenčíně, pp. 249-255.

Carayannis, E. G., Sindakis, S., \& Walter, C. (2015). Business model innovation as lever of organizational sustainability. The Journal of Technology Transfer, 40(1), 85-104.

Cassiman, B., \& Veugelers, R. (2006). In search of complementarity in innovation strategy: Internal R\&D and external knowledge acquisition. Management Science, 52(1), 68-82

Chatterjee, S., \& Hadi, A. S. (2015). Regression analysis by example. New York: John Wiley \& Sons.

Cohen, W. M., Nelson, R. R., \& Walsh, J. P. (2002). Links and impacts: the influence of public research on industrial R\&D. Management Science, 48(1), 1-23.

Cui, T., Ye, H. J., Teo, H. H., \& Li, J. (2015). Information technology and open innovation: A strategic alignment perspective. Information \& Management, 52(3), 348-358.

Dahlander, L., \& Gann, D. M. (2010). How open is innovation? Research Policy, 39(6), 699-709.

Damijan, J. P., Knell, M., Majcen, B., \& Rojec, M. (2003). The role of FDI, R\&D accumulation and trade in transferring technology to transition countries: evidence from firm panel data for eight transition countries. Economic Systems, 27(2), 189204.

Dudin, M. N., Voykova, N. A., Galkina, M. V., \& Vernikov, V. A. (2016). Development of Hungary's Manufacturing Industry in the Conditions of European Integration. International Journal of Economics and Financial Issues, 6(5S), 48-52.

Frenz, M., \& Ietto-Gillies, G. (2009). The impact on innovation performance of different sources of knowledge: Evidence from the UK Community Innovation Survey. Research Policy, 38(7), 1125-1135.

Grigoriou, K., \& Rothaermel, F. T. (2017). Organizing for knowledge generation: Internal knowledge networks and the contingent effect of external knowledge sourcing. Strategic Management Journal, 38(2), 395-414.

Grillitsch, M., \& Trippl, M. (2014). Combining knowledge from different sources, channels and geographical scales. European Planning Studies, 22(11), 2305-2325.

Hashmi, A. R. (2013). Competition and innovation: The inverted-U relationship revisited. Review of Economics and Statistics, 95(5), 1653-1668. 
Ingram, A. E., Lewis, M. W., Barton, S., \& Gartner, W. B. (2016). Paradoxes and innovation in family firms: The role of paradoxical thinking. Entrepreneurship Theory and Practice, 40(1), 161-176.

Jabagi, N., Jiang, J., MacLean, D., Chalmeau, S., \& Yang, J. (2016). Communicating to Practitioners through IS Research: a Descriptive Review. In Americas' Conference on Information System (AMCIS) 2016 Proceedings. San Diego: Association for Information Systems, pp. 1-10.

Jensen, M. B., Johnson, B., Lorenz, E., \& Lundvall, B. Å. (2007). Forms of knowledge and modes of innovation. In Lundvall, B. A. (Ed.), The learning economy and the economics of hope (pp. 155-182). London: Anthem Press.

Laursen, K., \& Salter, A. (2004). Searching high and low: what types of firms use universities as a source of innovation? Research policy, 33(8), 1201-1215.

Laursen, K., \& Salter, A. J. (2014). The paradox of openness: Appropriability, external search and collaboration. Research Policy, 43(5), 867-878.

Lee, A. S. (2000). The Social and Political Context of Doing Relevant Research, MIS Quarterly, 24(3), 355-355.

Leiponen, A., \& Helfat, C. E. (2010). Innovation objectives, knowledge sources, and the benefits of breadth. Strategic Management Journal, 31(2), 224-236.

Lin, H. F. (2007). Knowledge sharing and firm innovation capability: an empirical study. International Journal of Manpower, 28(3/4), 315-332.

McAdam, R., O’Hare, T., \& Moffett, S. (2008). Collaborative knowledge sharing in composite new product development: an aerospace study. Technovation, 28(5), 245-256.

Miotti, L., \& Sachwald, F. (2003). Co-operative R\&D: why and with whom?: An integrated framework of analysis. Research Policy, 32(8), 1481-1499.

Odei, S. A. (2017). Commercialization of Academic Research: Assessing the Enabling Conditions for German Universities. In European Conference on Innovation and Entrepreneurship. Academic Conferences International Limited, pp. 750-757.

Odei, S. A., Stejskal, J. (2018). Factors Influencing Spin-off Activities at Universities: Empirical Evidence from the United Kingdom., $21^{\text {st }}$ International Colloquium on Regional Sciences. Conference proceedings. Brno: Masaryk University, pp. 117124.

Perkmann, M., \& Walsh, K. (2007). University-industry relationships and open innovation: Towards a research agenda. International Journal of Management Reviews, 9(4), 259-280.

Perkmann, M., \& Walsh, K. (2008). Engaging the scholar: Three types of academic consulting and their impact on universities and industry. Research Policy, 37(10), 1884-1891.

Perkmann, M., Tartari, V., McKelvey, M., Autio, E., Broström, A., D’Este, P., ... \& Krabel, S. (2013). Academic engagement and commercialisation: A review of the literature on university-industry relations. Research Policy, 42(2), 423-442. 
Preacher, K. J., Curran, P. J., \& Bauer, D. J. (2006). Computational tools for probing interactions in multiple linear regression, multilevel modeling, and latent curve analysis. Journal of Educational and Behavioral Statistics, 31(4), 437-448

Prokop, V., \& Stejskal, J. (2018). Determinants of Innovation Activities: Public Financing and Cooperation: Case Study of Czech Republic and Hungary. In Modeling Innovation Sustainability and Technologies (pp. 77-91). Cham: Springer.

Santamaría, L., Nieto, M. J., \& Barge-Gil, A. (2009). Beyond formal R\&D: Taking advantage of other sources of innovation in low-and medium-technology industries. Research Policy, 38(3), 507-517.

Schneider, S., \& Spieth, P. (2013). Business model innovation: Towards an integrated future research agenda. International Journal of Innovation Management, 17(01), 1340001.

Siegel, D. S., Waldman, D. A., Atwater, L. E., \& Link, A. N. (2004). Toward a model of the effective transfer of scientific knowledge from academicians to practitioners: qualitative evidence from the commercialization of university technologies. Journal of Engineering and Technology Management, 21(1-2), 115-142.

Sorenson, O., \& Fleming, L. (2004). Science and the diffusion of knowledge. Research policy, 33(10), 1615-1634.

Stejskal, J., \& Hajek, P. (2012). Competitive advantage analysis: a novel method for industrial clusters identification. Journal of Business Economics and Management, 13(2), 344-365.

Straub, D. W., and Ang, S. (2008). Readability and the Relevance Versus Rigor Debate. MIS Quarterly, 32(4), 3-13.

Straub, D. W., and Ang, S. (2011). Rigor and relevance in IS research: Redefining the debate and a call for future research. MIS Quarterly, 35(1), 3-11.

Tether, B. S. (2002). Who co-operates for innovation, and why: an empirical analysis. Research policy, 31(6), 947-967.

Vrontis, D., Thrassou, A., Santoro, G., \& Papa, A. (2017). Ambidexterity, external knowledge and performance in knowledge-intensive firms. The Journal of Technology Transfer, 42(2), 374-388.

West, J., \& Bogers, M. (2014). Leveraging external sources of innovation: a review of research on open innovation. Journal of Product Innovation Management, 31(4), 814-831.

Yeniyurt, S., Henke, J. W., \& Yalcinkaya, G. (2014). A longitudinal analysis of supplier involvement in buyers' new product development: working relations, interdependence, co-innovation, and performance outcomes. Journal of the Academy of Marketing Science, 42(3), 291-308.

Zhang, F., \& Gallagher, K. S. (2016). Innovation and technology transfer through global value chains: Evidence from China's PV industry. Energy Policy, 94, 191-203. 


\section{Authors}

\section{Samuel Amponsah Odei}

University of Pardubice

Faculty of Economics and Administration

Studentska 95, Pardubice, Czech Republic

samuelamponsah.odei@upce.cz

\section{Jan Stejskal}

University of Pardubice

Faculty of Economics and Administration

Studentska 95, Pardubice, Czech Republic

jan.stejskal@upce.cz 